\title{
Byssinosis: a follow-up study of cotton ginnery workers in the Sudan
}

\author{
MUSTAFA KHOGALI \\ TUC Centenary Institute of Occupational Health, London School of Hygiene and Tropical \\ Medicine
}

\begin{abstract}
Khogali, M. (1976). British Journal of Industrial Medicine, 33, 166-174. Byssinosis: a follow-up study of cotton ginnery workers in the Sudan. A follow-up study of lung function tests and dust measurements was undertaken in ginnery workers employed in five ginning factories. Respiratory symptoms and respiratory function tests $\left(\right.$ FEV $_{1}$ and FVC) were first recorded in 1967 on a total of 382 workers ( 323 permanently employed ginnery workers, 35 seasonal farfara workers, and 24 fire brigade men as controls). In 1969 after a six-month break from ginning before the start of the season, a follow-up study of lung function tests was undertaken on $96 \%$ of the same workers (306 ginnery workers, 35 farfara, and 24 fire brigade men). Because of the lapse of two years a new adjustment for age and height was made so as to compare the FEV 1 measured in the follow-up study. The fire brigade men showed an expected fall in $F_{E V}$ during the two-year period, whereas the ginnery workers showed a rise presumably because they had had no dust exposure during the previous six months. The differences between the degree of change in these groups were statistically significant. In 1967 only the fine dust $(<7 \mu \mathrm{m})$ was measured, while in 1969 the concentration of fine and medium dust, that is, less fly was measured. The factories were divided into three groups according to dust concentration. Comparison between the three factory groups and farfara shows a positive association between the level of dust concentration less fly and the prevalence of cough and phlegm. Since age did not appear to be a significant factor in the prevalence of byssinosis, comparisons between permanent workers in these three groups of factories and farfara workers taken separately were made without age standardization. The overall differences were statistically significant. There was a marked trend showing a positive association between prevalence of byssinosis and level of cotton dust concentration in the factories. The correlation between dust levels and the prevalence of byssinosis was nearly perfect when the time factor was included.
\end{abstract}

The first part of this study was described earlier (Khogali, 1969). It is an epidemiological study which covered the five cotton ginning factories (factories 1 , 2, 3, 4, and 5) in the Maringan area in the Sudan. In 1967 a total of 382 men were examined comprising 323 permanent ginnery workers, a random sample of 35 seasonal farfara workers, and a control group of 24 members of the fire brigade. The study showed a prevalence of byssinosis (defined as chest tightness starting on return from the annual holiday and continuing for at least three consecutive days) in $20 \%$ of the ginnery workers and in $48.6 \%$ of the farfara workers.

In 1969 after a six-month break from ginning before the start of the season a follow-up study of lung function tests was undertaken on the same workers.

In 1967 only the concentration of fine dusts was measured. But in 1969 both fine $(<7 \mu \mathrm{m})$ and medium $(7 \mu \mathrm{m}-2 \mathrm{~mm})$ dusts were recorded, that is, the concentration of dust, less fly. The concentration, less fly is 'the weight of dust in milligrams per cubic 
metre of air, excluding particles which would be caught by a $2 \mathrm{~mm}$ wire mesh gauze, wire diameter $0.2 \mathrm{~mm}, 1.8 \mathrm{~mm}$ square aperture' (British Occupational Hygiene Society, 1972).

As described in the previous paper the survey of workers included the observation of symptoms of byssinosis, cough, cough and phlegm, and smoking habits. These were also analysed. The purpose of this paper is to report upon the results of the follow-up study and to discuss the association between the prevalence of byssinosis and other respiratory symptoms with the dust concentration, less fly. Our findings are particularly relevant since the new hygiene standards adopted by the BOHS (British Occupational Hygiene Society, 1972) for cotton dust.

\section{Population and methods}

Details of the population, the definition of byssinosis, the measurement of ventilatory capacity, and dust concentration were given in the previous paper, but the features relevant to this paper are summarized below.

The population covered in the follow-up study comprised 365 male workers compared with 382 workers in 1967 (Table 1). These were 48 ginnery workshop workers, 258 ginnery hall workers, 35 seasonal workers, and 24 controls. The 17 not examined were all permanently employed, 13 in the ginnery hall and four in the ginnery workshop. Two had been pensioned, six transferred, and nine were on different training courses. The permanent workers are divided among the five factories while only four factories had farfara sections.

\section{Dust measurement}

Dust sampling was carried out at the same sites as in 1967 when the same grades of cotton were ginned. Two hexhlets running in parallel were used (Roach and Schilling, 1960). The horizontal elutriator was removed and replaced by a $7 \mathrm{~cm}$ diameter wire gauze with square holes $2 \mathrm{~mm} \times 2 \mathrm{~mm}$. Air was drawn in by a vacuum pump at the rate of 50 litres per minute. Samples were obtained during an eight-hour period.

The long fibres ( $>2 \mathrm{~mm}$ ) settled on the gauze, that is, coarse dust or fly. The gauze should have been wiped periodically and the coarse dust weighed. However, in the very dusty conditions of the Maringan factories, especially near the farfara (Fig. 1), it was impractical to do this because the front of the elutriator had to be wiped every half-an-hour to remove the fluffs of cotton, so only fine and medium dusts were measured (dust less fly). The concentration of the medium dust was obtained indirectly.

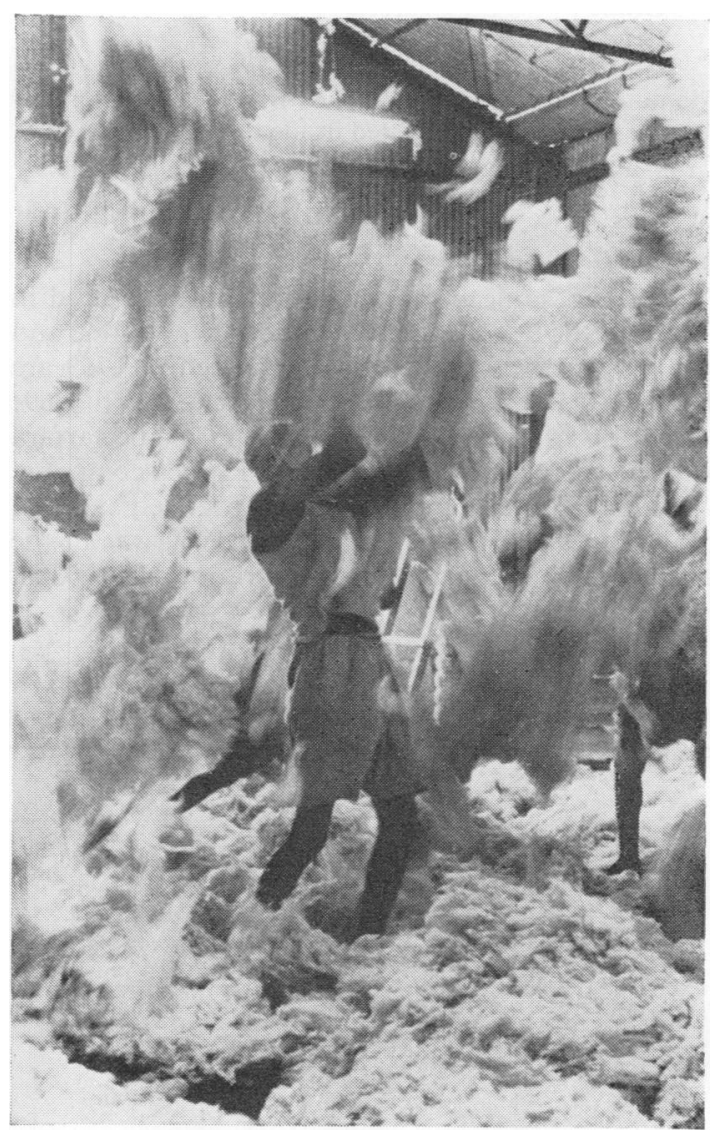

FIG. 1. The process of farfara. 
Classification of smoking habits

Each worker was asked about his smoking habit, and was subsequently classified as follows:

Non-smoker: worker who has never smoked as much as one cigarette a day for one year

Ex-smoker: worker who has smoked but had ceased smoking more than one month before the survey

Smoker:

Grade I 1-4 cigarettes a day

Grade II 5-14 cigarettes a day

Grade III 15 + cigarettes a day.

The number of cigarettes smoked by the smokers is low because smoking is prohibited inside the ginneries area.

\section{Results}

\section{Dust concentrations}

The average concentration of fine dust measured in 1967 and the average concentration of both fine and medium dust, that is less fly, measured in 1969 are shown in Table 2. More samples were taken in 1969: a total of 54 in the ginnery halls, 35 in the farfara sections, and 15 in the ginnery workshops compared with ten, eight, and two samples respectively taken in 1967. The highest concentration in 1969 was in the farfara which had a mean concentration of fine dust of $2.17 \mathrm{mg} / \mathrm{m}^{3}$ and of medium dust of $12.11 \mathrm{mg} / \mathrm{m}^{3}$; the lowest was in the ginnery workshops which had a mean concentration of $0.26 \mathrm{mg} / \mathrm{m}^{3}$ and $0.66 \mathrm{mg} / \mathrm{m}^{3}$ for fine and medium dust. The ginnery halls had a mean concentration of fine dust of $0.90 \mathrm{mg} / \mathrm{m}^{3}$ and of medium dust of $2.64 \mathrm{mg} / \mathrm{m}^{3}$.

In 1967 the mean fine dust concentration in factories 1,2 , and 3 was $0.67,0.62,0.58 \mathrm{mg} / \mathrm{m}^{3} \mathrm{re}-$ spectively so they were grouped together. In 1969 these three factories had mean fine dust concentrations of $0.95,0.86$, and $0.81 \mathrm{mg} / \mathrm{m}^{3}$ respectively and were again grouped together. The overall mean concentration in these three factories was $0.89 \mathrm{mg} / \mathrm{m}^{3}$ of fine dust and $2.77 \mathrm{mg} / \mathrm{m}^{3}$ of medium dust. Factory 5 had a mean concentration of $0.45 \mathrm{mg} / \mathrm{m}^{3}$ fine dust and $1.78 \mathrm{mg} / \mathrm{m}^{3}$ medium dust, compared with 1.33 $\mathrm{mg} / \mathrm{m}^{3}$ fine dust and $2.98 \mathrm{mg} / \mathrm{m}^{3}$ medium dust in factory 4 .

\section{Smoking}

The smoking habits and percentages of non-smokers and smokers are shown in Table 3a. Eleven $(45 \cdot 8 \%$ of the control group were smokers; of these, 10 had smoked 5-14 cigarettes a day for a mean period of 11.3 years and one had smoked more than 15 cigar-

TABLE 2

Dust Concentration, Classified by Factories for 1967 and 1969

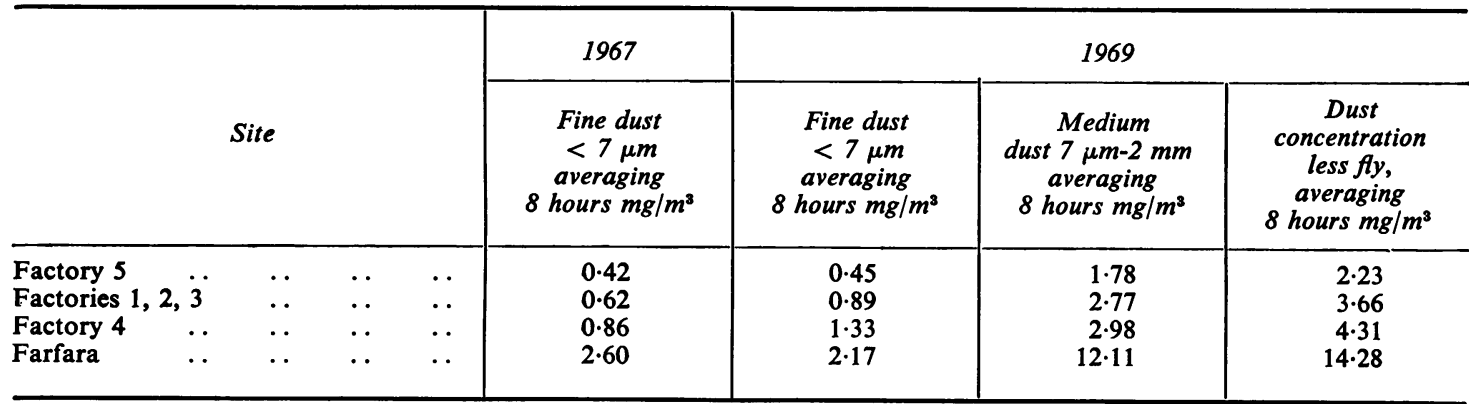

TABLE 3a

Smoking Habits Classified by Job aNd Factories (1967)

\begin{tabular}{|c|c|c|c|c|c|c|c|c|c|c|}
\hline \multirow{2}{*}{\multicolumn{4}{|c|}{ Work place }} & \multirow{2}{*}{$\begin{array}{c}\text { No. of } \\
\text { workers }\end{array}$} & \multicolumn{2}{|c|}{ Non-smokers } & \multicolumn{2}{|c|}{ Ex-smokers } & \multicolumn{2}{|c|}{ All smokers } \\
\hline & & & & & & & & & & \\
\hline $\begin{array}{l}\text { Control } \\
\text { Ginnery workshop } \\
\text { Ginnery hall } \quad . . \\
\text { Farfara .. }\end{array}$ & $\begin{array}{l}\cdots \\
\cdots \\
\cdots\end{array}$ & $\begin{array}{l}\cdots \\
\cdots \\
\cdots \\
\cdots\end{array}$ & $\begin{array}{l}\cdots \\
\cdots \\
\cdots\end{array}$ & $\begin{array}{r}24 \\
52 \\
271 \\
35\end{array}$ & $\begin{array}{r}13 \\
38 \\
166 \\
32\end{array}$ & $\begin{array}{l}54 \cdot 2 \\
73 \cdot 1 \\
61 \cdot 3 \\
91 \cdot 4\end{array}$ & $\begin{array}{l}- \\
6 \\
-\end{array}$ & $\begin{array}{l}\overline{5 \cdot 8} \\
2 \cdot 2 \\
-\end{array}$ & $\begin{array}{r}11 \\
11 \\
99 \\
3\end{array}$ & $\begin{array}{r}45 \cdot 8 \\
21 \cdot 1 \\
36 \cdot 5 \\
8 \cdot 6\end{array}$ \\
\hline $\begin{array}{l}\text { Factory } 5 \\
\text { Factories 1, 2, } 3 \\
\text { Factory } 4\end{array}$ & $\begin{array}{l}\cdots \\
\cdots \\
\cdots\end{array}$ & $\begin{array}{l}. \\
\cdots \\
.\end{array}$ & $\begin{array}{l}\ldots \\
\cdots \\
\ldots\end{array}$ & $\begin{array}{r}55 \\
193 \\
75\end{array}$ & $\begin{array}{r}32 \\
126 \\
46\end{array}$ & $\begin{array}{l}58 \cdot 2 \\
65 \cdot 3 \\
61 \cdot 3\end{array}$ & $\begin{array}{l}\overline{8} \\
1\end{array}$ & $\begin{array}{l}\overline{4 \cdot 1} \\
1 \cdot 3\end{array}$ & $\begin{array}{l}23 \\
59 \\
28\end{array}$ & $\begin{array}{l}41 \cdot 8 \\
30 \cdot 6 \\
37 \cdot 3\end{array}$ \\
\hline
\end{tabular}


ettes a day for 18 years (Table $3 b)$ ). Eleven $(21 \cdot 1 \%$ ) of the ginnery workshop workers were smokers. Three were grade I smokers for a mean period of 18.3 years, seven were grade II for a mean smoking period of 7.6 years, and only one was grade III. Out of 271 ginnery hall workers $99(36.5 \%)$ were smokers. Out of these $\mathbf{4 2}$ were grade I, 51 grade II, six grade III for a mean smoking period of 6.4 years, 7.8 years, and 5.3 years respectively. Only three $(8.6 \%)$ of the farfara workers were smokers. The permanent workers showed no great differences in their smoking habits and degree of smoking when compared by factories.

\section{Ventilatory function}

To compare the occupational groups of the FEV 1 measured in the follow-up study in 1969, a new adjustment for age and height was made. Since the workers were older, the observed $\mathrm{FEV}_{1}$ were corrected to give the expected value for the new average age of 33 years and a standard height of $171 \mathrm{~cm}$. The regression of $\mathrm{FEV}_{1}$ on age, independent of height (b1), was -0.033 to -0.018 litres and the regression of height, independent of age (b2), was +0.037 litres per $\mathrm{cm}$ with $95 \%$ confidence limits of +0.027 to +0.046 litres.

The mean adjusted $\mathrm{FEV}_{1}$ for age and height in the occupational groups measured in 1967 and in 1969 after a period of two years, the last six months being free of dust, is shown in Table 4. An analysis of covariance showed that there was no statistically significant difference between the slopes, and the data were pooled to give a common regression line which was used to adjust the mean $\mathrm{FEV}_{1}$ in the four groups. The overall differences of the mean adjusted $F V_{1}$ were found to be statistically significant at the 0.001 level. The mean change between the FEV $_{1}$ measured in 1967 and that measured in 1969 is shown for each group in Table 5. While the control men showed no change in $\mathrm{FEV}_{1}$ during the twoyear period, all the other groups of the ginnery workers showed a rise. When comparisons were

TABLE $3 b$

Grades of Smoking and Mean Smoking Period of Smokers Among Ginnery Workers Classified by Work Place (1967)

\begin{tabular}{|c|c|c|c|c|c|c|c|c|c|}
\hline \multirow[b]{2}{*}{ Degree of smoking } & & \multicolumn{2}{|c|}{ Control } & \multicolumn{2}{|c|}{ Ginnery workshop } & \multicolumn{2}{|c|}{ Ginnery hall } & \multicolumn{2}{|c|}{ Farfara } \\
\hline & & $\begin{array}{l}\text { No. of } \\
\text { smokers }\end{array}$ & $\begin{array}{c}\text { Mean } \\
\text { smoking } \\
\text { period } \\
(y r)\end{array}$ & $\begin{array}{c}\text { No. of } \\
\text { smokers }\end{array}$ & $\begin{array}{c}\text { Mean } \\
\text { smoking } \\
\text { period } \\
(y r)\end{array}$ & $\begin{array}{c}\text { No. of } \\
\text { smokers }\end{array}$ & $\begin{array}{c}\text { Mean } \\
\text { smoking } \\
\text { period } \\
(y r)\end{array}$ & $\begin{array}{c}\text { No. of } \\
\text { smokers }\end{array}$ & $\begin{array}{c}\text { Mean } \\
\text { smoking } \\
\text { period } \\
(y r)\end{array}$ \\
\hline $\begin{array}{l}\text { Grade I } \\
1-4 \text { cigarettes/day } \\
\text { Grade II } \\
5-14 \text { cigarettes/day } \\
\text { Grade III } \\
15+\text { cigarettes/day }\end{array}$ & $\cdots$ & $\begin{array}{r}- \\
10 \\
1\end{array}$ & $\begin{array}{l}- \\
11 \cdot 3 \\
18 \cdot 0\end{array}$ & $\begin{array}{l}3 \\
7 \\
1\end{array}$ & $\begin{array}{r}18 \cdot 3 \\
7 \cdot 6 \\
13 \cdot 0\end{array}$ & $\begin{array}{r}42 \\
51 \\
6\end{array}$ & $\begin{array}{l}6 \cdot 4 \\
7 \cdot 8 \\
5 \cdot 3\end{array}$ & $\begin{array}{l}2 \\
- \\
1\end{array}$ & $\begin{array}{l}6.5 \\
- \\
4.0\end{array}$ \\
\hline All smokers & . & 11 & 11.9 & 11 & $11 \cdot 0$ & 99 & $7 \cdot 1$ & 3 & $5 \cdot 7$ \\
\hline
\end{tabular}

TABLE 4

Mean FEV 1 Adjusted for Age and Height Classified by Work Place in 1967 and 1969

\begin{tabular}{|c|c|c|c|c|c|c|c|c|c|}
\hline \multirow[b]{2}{*}{ Work place } & & \multicolumn{4}{|c|}{1967} & \multicolumn{4}{|c|}{1969} \\
\hline & & $\begin{array}{c}\text { No. of } \\
\text { workers }\end{array}$ & $\begin{array}{c}\text { Mean } \\
\text { age }(y r)\end{array}$ & $\begin{array}{c}\text { Mean } \\
\text { height } \\
(\mathrm{cm})\end{array}$ & $\begin{array}{l}\text { Mean' } \\
\text { FEV } \\
\text { adjusted } \\
\text { BTPS/ } \\
\text { litres }\end{array}$ & $\begin{array}{c}\text { No. of } \\
\text { workers }\end{array}$ & $\begin{array}{c}\text { Mean } \\
\operatorname{age}(y r)\end{array}$ & $\begin{array}{c}\text { Mean } \\
\text { height } \\
(\mathrm{cm})\end{array}$ & $\begin{array}{l}\text { Mean }^{2} \\
\text { FEV } \\
\text { adjusted } \\
\text { BTPS/ } \\
\text { litres }\end{array}$ \\
\hline $\begin{array}{l}\text { Control } \quad \text {. } \\
\text { Ginnery workshop } \\
\text { Ginnery hall } \\
\text { Farfara } \quad \text {. }\end{array}$ & $\begin{array}{l}\ldots \\
\cdots \\
\cdots \\
.\end{array}$ & $\begin{array}{r}24 \\
52 \\
271 \\
35\end{array}$ & $\begin{array}{l}35 \\
32 \\
31 \\
30\end{array}$ & $\begin{array}{l}177 \\
170 \\
171 \\
167\end{array}$ & $\begin{array}{l}3 \cdot 08 \\
3 \cdot 02 \\
2 \cdot 77 \\
2 \cdot 20\end{array}$ & $\begin{array}{r}24 \\
48 \\
258 \\
35\end{array}$ & $\begin{array}{l}37 \\
34 \\
33 \\
32\end{array}$ & $\begin{array}{l}177 \\
171 \\
171 \\
167\end{array}$ & $\begin{array}{l}3 \cdot 08 \\
3 \cdot 38 \\
3 \cdot 22 \\
2 \cdot 49\end{array}$ \\
\hline
\end{tabular}

${ }^{1}$ Adjusted to a standard age of 31 years and a height of $171 \mathrm{~cm}$.

${ }^{2}$ Adjusted to a standard age of 33 years and a height of $171 \mathrm{~cm}$; this was measured after 6 months' dust exposure. 


\section{TABLE 5}

Mean Change in FeV 1 During a Period of Two Years. (The Last Six Months Being Free From EXPOSURE to DUST (1969))

\begin{tabular}{l|c|c|c}
\hline Work place & $\begin{array}{c}\text { No. of } \\
\text { workers }\end{array}$ & $\begin{array}{c}\text { Mean } \\
\text { change } \\
\text { FEV } \\
\text { BTPS/ } \\
\text { litres }\end{array}$ & $\begin{array}{c}\text { Dust } \\
\text { concentration } \\
\text { less } \text { fly, } \\
\text { averaging } \\
\text { hours } \mathrm{mg} / \mathrm{m}^{3}\end{array}$ \\
\hline $\begin{array}{l}\text { Control .. } \\
\text { Ginnery } \\
\text { workshop }\end{array}$ & 24 & -0.002 & - \\
$\begin{array}{l}\text { Ginnery hall } \\
\text { Farfara .. }\end{array}$ & 258 & +0.30 & 0.92 \\
& 35 & +0.43 & 3.54 \\
\hline
\end{tabular}

Statistically significant difference between occupational groups: Control v. ginnery workshop SE (difference) = $0.15 ; t=2.00 \mathrm{P}<0.05 ;$ Control v. ginnery hall SE (difference) $=0.13 ; t=3.42 \mathrm{P}<0.001$

made between the mean change in $\mathrm{FEV}_{1}$ of the control men and that of the men in the ginnery workshop the difference was statistically significant $(P<0.05)$; and a highly significant difference was found between the control men and the ginnery hall workers $(\mathrm{P}<0.001)$.

\section{Respiratory symptoms and dust concentration}

The prevalence of cough and cough with phlegm in the control and in the ginnery workers classified by factories according to dust concentration, less fly, is shown in Table 6. None of the control group had a cough, $9.1 \%$ of the permanent workers in factory 5 had coughs, while the prevalence was $17 \cdot 1 \%$ and
$24.0 \%$ among workers in factories 1,2 , and 3 combined, and factory 4 . Only three $(8.6 \%)$ of the farfara workers had coughs. Since there was little difference in mean age between the workers in the five factories the comparison between workers in factory 5 , factories 1,2 , and 3 , and factory 4 was made on all ages combined, standardized for smoking habits. The overall differences between the groups were found to be statistically significant $\left(\chi^{2}=11.0, \mathbf{P}<0.02\right)$. There appeared to be a positive association between the prevalence of cough and dust level in the three factory groups, but this did not extend to the farfara workers and therefore no test for linear trend was made.

\section{Cough and phlegm}

The prevalence of cough and phlegm classified by smoking habit and job is shown in Table 7a. Applying Cochran's test for difference between percentages, after standardizing for age and job, the difference between smokers and non- or ex-smokers was not statistically significant. The overall differences between jobs standardized for age were highly significant $\left(P<0.001, \chi^{2}=17.87\right)$. When separate comparisons were made between jobs, standardized for age, statistically significant differences were found between those who worked in the ginnery workshop and the ginnery hall $(\mathrm{P}<0.05)$, between the control and the farfara workers $(\mathrm{P}<0.01)$, between the ginnery hall and farfara workers $(\mathrm{P}<$ 0.01 , and between the ginnery workshop and farfara $(P<0.001)$.

Since there were statistically significant differences between men employed in the ginnery workshop and those in the ginnery hall new comparisons were

TABLE 6

Prevalence of Cough, Cough and Phlegm, No Respiratory Symptoms, Classified By Factories and Related to Dust ConCentration Less Fly (1969)

\begin{tabular}{|c|c|c|c|c|c|c|c|c|c|c|}
\hline \multicolumn{4}{|c|}{ Group } & \multicolumn{2}{|c|}{ Cough $^{1}$} & \multicolumn{2}{|c|}{ Cough and phlegm } & \multicolumn{2}{|c|}{$\begin{array}{l}\text { No respiratory }{ }^{2} \\
\text { symptoms }\end{array}$} & \multirow{2}{*}{$\begin{array}{c}\text { Dust concentration } \\
\text { (less fy) averaging } \\
8 \text { hours } \mathrm{mg} / \mathrm{m}^{8}\end{array}$} \\
\hline & & & & No. & $\%$ & No. & $\%$ & No. & $\%$ & \\
\hline $\begin{array}{l}\text { Control } \\
\text { Factory } 5 \\
\text { Factory } 1,2 \\
\text { Factory } 4 \\
\text { Farfara }\end{array}$ & $\begin{array}{l}\ddot{ } \\
\ddot{2}, 3 \\
\therefore \\
\cdots\end{array}$ & $\begin{array}{l}\ldots \\
\ldots \\
\ldots \\
\ldots\end{array}$ & $\begin{array}{l}\cdots \\
\cdots \\
\cdots \\
\cdots \\
\cdots\end{array}$ & $\begin{array}{r}-5 \\
33 \\
18 \\
3\end{array}$ & $\begin{array}{r}- \\
9 \cdot 1 \\
17 \cdot 1 \\
24 \cdot 0 \\
8 \cdot 6\end{array}$ & $\begin{array}{r}1 \\
2 \\
20 \\
8 \\
10\end{array}$ & $\begin{array}{r}4 \cdot 2 \\
3 \cdot 6 \\
10 \cdot 4 \\
10 \cdot 7 \\
28 \cdot 6\end{array}$ & $\begin{array}{r}23 \\
39 \\
100 \\
28 \\
4\end{array}$ & $\begin{array}{l}95 \cdot 8 \\
70 \cdot 9 \\
51 \cdot 8 \\
37 \cdot 3 \\
11 \cdot 4\end{array}$ & $\begin{array}{r}\overline{2 \cdot 23} \\
3 \cdot 66 \\
4 \cdot 31 \\
14 \cdot 28\end{array}$ \\
\hline
\end{tabular}

1Overall difference between the groups statistically significant $\left(\chi^{2}=11 \cdot 0, \mathrm{P}<0.02\right)$.

${ }^{2}$ Statistically significant differences between factories and all farfara:
Factory 5
v. Factory $1+2+3$
Normal deviate $=2.77 \mathrm{P}<0.01$
Factory 5
v. Factory 4
v. Farfara
Factories $1+2+3$ v. Farfara
Factories $1+2+3$ v. Factory 4
Factory 4
v. Farfara

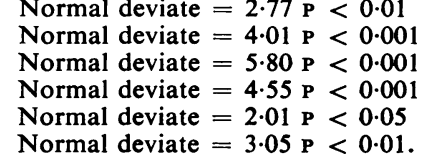


made between factory 4 , factories 1,2 , and 3 , and factory 5 (Table 6) after standardizing for job. The difference was not statistically significant.

\section{No respiratory symptoms}

The proportion of ginnery workers with no respiratory symptoms, classified by factory, is shown in Table 6. Since age did not appear to be a significant factor in the percentage of workers with no respiratory symptoms, comparisons between permanent workers in factory 5 , factories 1,2 , and 3 , factory 4 , and all farfara workers were made on all ages combined. The overall differences, standardizing for smoking habits, were highly significant $\left(\chi^{2}=38.03\right.$, $P<0.001$ ). When separate comparisons were made between the permanent workers in the factories and all farfara workers significant differences were found between factory 5 and factories 1,2 , and 3 $(P<0.01)$, between factory 5 and factory 4 $(\mathrm{P}<0.001)$, between factory 5 and farfara $(\mathrm{P}<0.001)$, between factories 1,2 , and 3 and factory $4(\mathrm{P}<0.05)$, between factories 1,2 , and 3 and farfara $(P<0.001)$ and between factory 4 and farfara $(P<0.01)$.

There was some association between freedom from chest symptoms and the level of dust exposure, but this differed slightly in the two smoking habit groups, the non- and ex-smokers appearing to benefit much more than the smokers from the relatively low level of dust in factory 5 (Table $7 \mathrm{~b}$ ).

\section{Byssinosis}

The prevalence of byssinosis classified by smoking habit, age, and occupational group is shown in Table 8. Using Cochran's test, standardizing for age and job, the difference between smokers and non/ ex-smokers was not statistically significant. Similarly there was no statistically significant difference between the age groups 15-34 years and 35-54 years after standardizing for job and smoking. The $\chi^{2}$ test, comparing jobs standardized for age and smoking, showed overall differences to be statistically significant $\left(\chi^{2}=15.91, \mathrm{P}<0.001\right)$.

Table 9 shows the prevalence of byssinosis classified by factories and age groups. Since age did not appear to be a significant factor in the prevalence of byssinosis, comparisons between permanent workers in factory 5 , factories 1,2 , and 3 , factory 4 and all farfara workers were made on all ages combined.

TABLE 7a

Prevalence of Cough and Phlegm Classified by Smoking Habits and Job (1967)

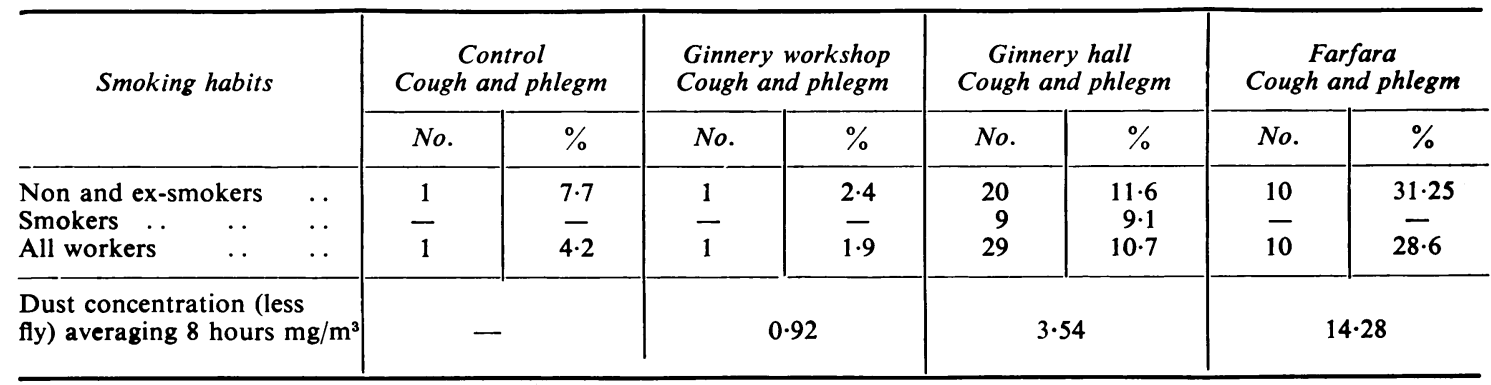

TABLE 7b

Proportion of GinNery Workers With No Respiratory SyMptoms Classified by Smoking Habits and Factories (1969)

\begin{tabular}{|c|c|c|c|c|c|c|c|c|c|}
\hline \multirow{3}{*}{ Smoking habits } & & \multicolumn{8}{|c|}{ No respiratory symptoms } \\
\hline & & \multicolumn{2}{|c|}{ Factory 5} & \multicolumn{2}{|c|}{ Factory 1,2 , and 3} & \multicolumn{2}{|c|}{ Factory 4} & \multicolumn{2}{|c|}{ Farfara } \\
\hline & & No. & $\%$ & No. & $\%$ & No. & $\%$ & No. & $\%$ \\
\hline $\begin{array}{l}\text { Non and ex-smokers } \\
\text { Smokers } \ldots\end{array}$ & $\begin{array}{l}\cdots \\
\cdots\end{array}$ & $\begin{array}{l}27 \\
12\end{array}$ & $\begin{array}{l}84 \cdot 4 \\
52 \cdot 2\end{array}$ & $\begin{array}{l}74 \\
26\end{array}$ & $\begin{array}{l}55 \cdot 2 \\
44 \cdot 1\end{array}$ & $\begin{array}{r}21 \\
7\end{array}$ & $\begin{array}{l}44 \cdot 7 \\
25 \cdot 0\end{array}$ & $\begin{array}{l}3 \\
1\end{array}$ & $\begin{array}{r}9 \cdot 4 \\
33 \cdot 0\end{array}$ \\
\hline All workers & . & 39 & $70 \cdot 9$ & 100 & $51 \cdot 8$ & 28 & $37 \cdot 3$ & 4 & $11 \cdot 4$ \\
\hline
\end{tabular}

Factory 5 v. factories 1,2 , and 3

Factory 5 v. factory 4

Normal deviate $=2.77 \mathrm{P}<0.01$

Factory 5 v. farfara

Normal deviate $=4.01 \mathrm{P}<0.001$

Normal deviate $=5.80 \mathrm{P}<0.001$ 
The overall differences were statistically significant $\left(\chi^{2}=9.21, \mathrm{P}<0.05\right)$. The prevalence of byssinosis classified by factories and showing the relevant dust concentration and years of exposure is shown in Table 10. There is a marked trend showing a positive association between prevalence of byssinosis and level of dust concentration, less fly, in the factories
(Fig. 2). The $\chi^{2}$ test for trend, with one degree of freedom, showed a statistically significant trend, $\chi^{2}=$ $9 \cdot 19, \mathrm{P}<0.01$. The regression calculated as a straight line gives a prevalence of $8.2 \%$ at 0 dust concentration and $25.48 \%$ at a dust concentration of $6.0 \mathrm{mg} /$ $\mathrm{m}^{3}$. The correlation coefficient is +0.9777 . When this relationship was re-examined taking into account

TABLE 8

Prevalence of Byssinosis Classified by Smoking Habits, Age, and Jobs (1967)

\begin{tabular}{|c|c|c|c|c|c|c|c|c|c|c|}
\hline \multirow{2}{*}{\multicolumn{3}{|c|}{ Smoking habits }} & \multicolumn{2}{|c|}{ Ginnery workers } & \multicolumn{2}{|c|}{ Ginnery hall } & \multicolumn{2}{|c|}{ Farfara } & \multicolumn{2}{|c|}{ All ginnery workers } \\
\hline & & & No. & $\%$ & No. & $\%$ & No. & $\%$ & No. & $\%$ \\
\hline $\begin{array}{c}\text { Non and ex-s } \\
\text { Age } 15-34 \\
35-54\end{array}$ & $\begin{array}{l}\text { kers } \\
\cdots \\
\ldots\end{array}$ & $\begin{array}{l}\cdots \\
\cdots\end{array}$ & $\begin{array}{l}5 \\
1\end{array}$ & $\begin{array}{c}20 \cdot 8 \\
6 \cdot 25\end{array}$ & $\begin{array}{l}20 \\
11\end{array}$ & $\begin{array}{l}18 \cdot 5 \\
17 \cdot 2\end{array}$ & $\begin{array}{r}11 \\
4\end{array}$ & $\begin{array}{l}47 \cdot 8 \\
44 \cdot 4\end{array}$ & $\begin{array}{l}36 \\
16\end{array}$ & $\begin{array}{l}23 \cdot 1 \\
18 \cdot 0\end{array}$ \\
\hline Total & . & .. & 6 & $14 \cdot 6$ & 31 & $18 \cdot 0$ & 15 & $46 \cdot 9$ & 52 & $21 \cdot 2$ \\
\hline $\begin{array}{r}\text { Smokers } \\
\text { Age } 15-34 \\
35-54\end{array}$ & $\begin{array}{l}\cdots \\
\ldots\end{array}$ & $\begin{array}{l}\ldots \\
\ldots\end{array}$ & $\begin{array}{l}3 \\
1\end{array}$ & $\begin{array}{l}50.0 \\
20.0\end{array}$ & $\begin{array}{r}17 \\
3\end{array}$ & $\begin{array}{l}23 \cdot 0 \\
12 \cdot 0\end{array}$ & $\frac{2}{-}$ & $\begin{array}{c}66 \cdot 7 \\
-\end{array}$ & $\begin{array}{r}22 \\
4\end{array}$ & $\begin{array}{l}26.5 \\
13 \cdot 3\end{array}$ \\
\hline Total & . & . & 4 & $36 \cdot 4$ & 20 & $20 \cdot 2$ & 2 & $66 \cdot 7$ & 26 & $23 \cdot 0$ \\
\hline $\begin{array}{r}\text { All workers } \\
\text { Age } 15-34 \\
35-54\end{array}$ & $\begin{array}{l}\cdots \\
\cdots\end{array}$ & $\begin{array}{l}\cdots \\
\cdots\end{array}$ & $\begin{array}{l}8 \\
2\end{array}$ & $\begin{array}{r}25.8 \\
9.5\end{array}$ & $\begin{array}{l}37 \\
14\end{array}$ & $\begin{array}{l}20 \cdot 3 \\
15 \cdot 7\end{array}$ & $\begin{array}{r}13 \\
4\end{array}$ & $\begin{array}{l}50 \cdot 0 \\
44 \cdot 4\end{array}$ & $\begin{array}{l}58 \\
20\end{array}$ & $\begin{array}{l}24 \cdot 3 \\
16 \cdot 8\end{array}$ \\
\hline Total & . & . & 10 & $19 \cdot 2$ & 51 & $18 \cdot 8$ & 17 & $48 \cdot 6$ & 78 & $21 \cdot 8$ \\
\hline
\end{tabular}

TABLE 9

Prevalence of Byssinosis Classified by Age and Factories (1969)

\begin{tabular}{|c|c|c|c|c|c|c|c|c|c|c|}
\hline \multirow{2}{*}{\multicolumn{2}{|c|}{ Age }} & & \multicolumn{2}{|c|}{ Factory 5} & \multicolumn{2}{|c|}{ Factories 1, 2, 3} & \multicolumn{2}{|c|}{ Factory 4} & \multicolumn{2}{|c|}{ Farfara } \\
\hline & & & No. & $\%$ & $\mathrm{No}$ & $\%$ & No & $\%$ & $\mathrm{No}$ & $\%$ \\
\hline $\begin{array}{l}15-34 \text { years } \\
35-54 \text { years }\end{array}$ & $\begin{array}{l}\cdots \\
\cdots\end{array}$ & $\begin{array}{l}\cdots \\
\cdots\end{array}$ & $\begin{array}{l}5 \\
1\end{array}$ & $\begin{array}{r}13 \cdot 2 \\
5 \cdot 9\end{array}$ & $\begin{array}{r}28 \\
8\end{array}$ & $\begin{array}{l}21 \cdot 0 \\
13 \cdot 3\end{array}$ & $\begin{array}{r}12 \\
7\end{array}$ & $\begin{array}{l}28 \cdot 6 \\
21 \cdot 2\end{array}$ & $\begin{array}{r}13 \\
4\end{array}$ & $\begin{array}{l}50 \\
44 \cdot 4\end{array}$ \\
\hline Total & . & . & 6 & $10 \cdot 9$ & 36 & $18 \cdot 6$ & 19 & $25 \cdot 3$ & 17 & $48 \cdot 6$ \\
\hline
\end{tabular}

Statistically significant differences between groups, all ages combined $\chi^{2}=9 \cdot 21, \mathrm{P}<0.05$.

TABLE 10

Prevalence of Byssinosis Classified by Factories and Related to Dust Concentration, Less Fly and Time Weighted Dust Measurement (1969)

\begin{tabular}{|c|c|c|c|c|c|}
\hline \multirow{2}{*}{ Factory } & \multicolumn{2}{|c|}{ Byssinosis } & \multirow{2}{*}{ Years of exposure } & \multirow{2}{*}{$\begin{array}{c}\text { Dust concentration } \\
\text { (less } \mathrm{fly} \text { ) averaging } \\
8 \text { hours } \mathrm{mg} / \mathrm{m}^{3}\end{array}$} & \multirow{2}{*}{$\begin{array}{c}\text { Time weighted } \\
\text { dust measurements } \\
\text { mg/years per } m^{3}\end{array}$} \\
\hline & No. & $\%$ & & & \\
\hline $\begin{array}{l}\text { Factory } 5 \\
\text { Factories } 1,2,3 \ldots \\
\text { Factory } 4 \\
\text { Farfara }\end{array}$ & $\begin{array}{r}6 \\
36 \\
19 \\
17\end{array}$ & $\begin{array}{l}10 \cdot 9 \\
18 \cdot 6 \\
25 \cdot 3 \\
48 \cdot 6\end{array}$ & $\begin{array}{r}10 \\
9 \\
11 \\
6\end{array}$ & $\begin{array}{r}2 \cdot 23 \\
3 \cdot 66 \\
4 \cdot 31 \\
14 \cdot 28\end{array}$ & $\begin{array}{l}22 \cdot 30 \\
32 \cdot 94 \\
47 \cdot 41 \\
85 \cdot 68\end{array}$ \\
\hline
\end{tabular}




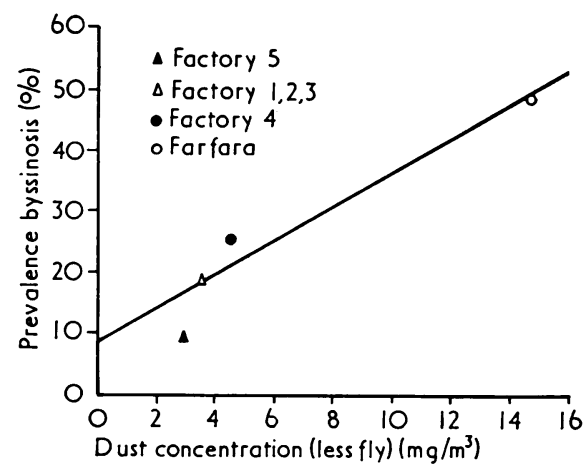

FIG. 2. Percentage byssinosis regressed against dust concentration.

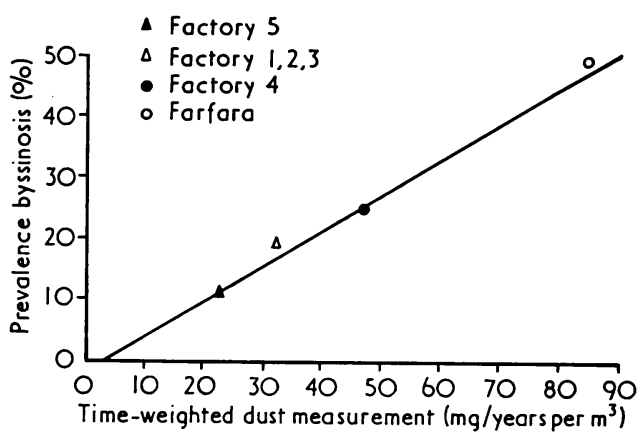

FIG. 3. Percentage byssinosis regressed against timeweighted dust measurement.

the years of exposure (time weighted dust concentration) an almost perfect linear trend was found (Fig. 3 ). The regression line gives a prevalence of $-1.75 \%$ at 0 dust concentration and $27.75 \%$ at $50 \mathrm{mg}$ years/ $\mathrm{m}^{3}$. The correlation coefficient is +0.999 .

\section{Discussion}

In this study an attempt has been made to relate the prevalence of byssinosis and other respiratory symptoms with the level and duration of exposure to cotton dust.

There appeared to be a positive relationship between the exposure to cotton dust and the symptoms of cough and phlegm (Tables 6,7$)$. In this study it was difficult to classify the workers complaining of cough and sputum as suffering from chronic bronchitis according to the Medical Research Council classification (1965). The very moderate smoking habits of the Sudanese ginnery workers do not appear to account for the high prevalence of cough and phlegm
(Tables 6,7) among the workers exposed to cotton dust when compared with the controls, although a higher proportion $(45.8 \%)$ of the controls smoked compared with ginnery workers $(31.6 \%)$. In the present study further evidence is given of the noxious effects of cotton dust inhalation on the respiratory tract and its role in the aetiology of cough and phlegm independent of any effects of smoking. Among the farfara workers who were exposed to high concentrations of cotton dust, $28.6 \%$ had persistent cough and phlegm, but none was a smoker or exsmoker (Table 7). Our conclusion is that there is some evidence of association between exposure to cotton dust, less fly, and the development of early bronchitis. This is in agreement with the findings of Berry, Molyneux, and Tombleson (1974) who reported an association between exposure to cotton dust and the development and retention of bronchitis. Fox et al. (1973b) reported there was no relationship between cotton dust and the prevalence of bronchitis. However, as Berry et al. (1974) observed, the Fox et al. (1973b) conclusion was based on a comparison of cotton workers with men working in engineering factories and as two-thirds of the cotton workers were women, a small difference between cotton and noncotton workers could have been lost.

\section{Byssinosis}

There is some evidence from surveys of textile workers that byssinotic symptoms are more prevalent among smokers than among non-smokers (Schilling, 1964; Elwood et al., 1965; Fox et al., 1973a; Merchant et al., 1973; Berry et al., 1974). In the present study the prevalence of byssinosis appeared to be independent of smoking: the difference in the prevalence of byssinosis in smokers, nonsmokers, and ex-smokers after standardizing for age and job was not statistically significant (Table 8). This agrees with other studies, where the prevalence of Monday dyspnoea was independent of smoking habits (Belin et al., 1965). In spite of these results the author considers that there is an association with smoking and thinks that the small number of cigarettes smoked by the Sudanese ginnery workers is the reason for his negative findings.

The prevalence of byssinosis is directly related to the level of cotton dust concentration, less fly (Table 10). Although Roach and Schilling (1960) found a correlation between total dust concentration and byssinosis prevalence, more recent evidence has suggested that the relationship with respirable particles, or fly-free dust (medium plus fine fractions) is more relevant (Roach, 1972; British Occupational Hygiene Society, 1972; Fox et al., 1973a; Berry et al., 1974; National Institute of Occupational Safety and Health, 1974). This evidence is strongly supported 
in these studies. Thus it seems that the determination of fly-free dust is the most practical method of assessing the environment in cotton ginneries and mills.

Previous studies (Schilling and Roach, 1961; Molyneux and Tombleson, 1970) showed that the effects of differences in duration of exposure were small in comparison with the effects of difference in concentration. Recently Fox et al. (1973a) expressed the dose-response relationship in terms of the timeweighted dust measurement $\left(\mathrm{mg}\right.$ years $/ \mathrm{m}^{3}$ ) that is, dust concentration $\times$ length of exposure in years. Such methods have been used in estimating the threshold limit values of asbestos workers (British Occupational Hygiene Society, 1968). This method was also applied in this study and an almost perfect relationship between the prevalence of byssinosis and the time-weighted dust measurement was found.

Although the association between the incidence of byssinosis and airborne cotton dust is strongly positive, the reasons for the production of symptoms of byssinosis and the changes in ventilatory capacity associated with the disease are not clear. Therefore until the mechanism can be better explained there is a need to use the available knowledge in prevention of over exposure to cotton dust and its noxious effects.

I am greatly indebted to Miss Joan Walford for her statistical help and to Professor R. S. F. Schilling for his advice.

\section{References}

Belin, L., Bouhuys, A., Hoekstra, W., Johansson, M. B., Lindell, S. E., and Pool, J. (1965). Byssinosis in cardroom workers in Swedish cotton mills. British Journal of Industrial Medicine, 22, 101-108.

Berry, G., Molyneux, M. K. B., and Tombleson, J. B. L. (1974). Relationships between dust level and byssinosis and bronchitis in Lancashire cotton mills. British Journal of Industrial Medicine, 31, 18-27.

British Occupational Hygiene Society (1968). Hygiene standards for chrysotile asbestos dust. Annals of Occupational Hygiene, 11, 47-69.

- (1972). Hygiene standards for cotton dust. Annals of Occupational Hygiene, 15, 165-192.
Elwood, P. C., Pemberton, J., Merrett, J. D., Carey, G. C. R., and McAulay, I. R. (1965). Byssinosis and other respiratory symptoms in flax workers in Northern Ireland. British Journal of Industrial Medicine, 22, 27-37.

Fox, A. J., Tombleson, J. B. L., Watt, A., and Wilkie, A. G. (1973a). A survey of respiratory disease in cotton operatives. Part I. Symptoms and ventilation test results. British Journal of Industrial Medicine, 30, 42-47.

,,--- , and - - (1973b). A survey of respiratory disease in cotton operatives. Part II. Symptoms, dust estimations, and the effect of smoking habit. British Journal of Industrial Medicine, 30, 48-53.

Khogali, M. (1969). A population study in cotton ginnery workers in the Sudan. British Journal of Industrial Medicine, 26, 308-313.

Medical Research Council (1965) Leading article. Definition and classification of chronic bronchitis for clinical and epidemiological purposes. Lancet, 1, 775-779.

Merchant, J. A., Lumsden, J. C., Kilburn, K. H., O'Fallen, W. M., Ujda, J. R., Germino, V. H., and Hamilton, J. D. (1973). An industrial study of the biological effects of cotton dust and cigarette smoke exposure. Journal of Occupational Medicine, 15, 212221.

Molyneux, M. K. B. and Tombleson, J. B. L. (1970). An epidemiological study of respiratory symptoms in Lancashire mills 1963-66. British Journal of Industrial Medicine, 17, 1-9.

National Institute of Occupational Safety and Health (1974). Criteria Document: Recommendations for an Occupational Exposure Standard for Cotton Dust, p. 89. US Department of Health, Education and Welfare, Washington, D.C.

Roach, S. A. (1972). Dust levels and disease. In Transactions of the National Conference on Cotton Dust and Health, University of North Carolina, School of Public Health, 1970, pp. 25-32. (Conference held on 2 May 1970, Charlotte, North Carolina, Chapel Hill.)

and Schilling, R. S. F. (1960). A clinical and environmental study of byssinosis in the Lancashire cotton industry. British Journal of Industrial Medicine, 17, 1-9.

Schilling, R. S. F. (1964). Epidemiological studies of chronic respiratory disease among cotton operatives. Yale Journal of Biology and Medicine, 37, 55-74. and Roach, S. A. (1961). Safe levels of dustiness in cotton spinning mills. Pure and Applied Chemistry, 3, 69.

Received for publication 4 November 1975

Accepted for publication 19 February 1976 